\title{
PERANAN BALAI PERMASYARAKATAN (BAPAS) DALAM PEMBIMBINGAN ANAK NAKAL DI MADIUN
}

\author{
Ninda Paramita Sari*
}

\begin{abstract}
Abstrak
Tenakalan anak memberi dorongan kuat bagi pihak-pihak yang bertanggung jawab untuk lebih memperhatikan masalah kenakalan anak 1 khususnya balai permasyarakatan (BAPAS). Penelitian ini dilaksanakan di Balai Pemasyarakatan Kelas II Madiun.Penelitian ini menggunakan pendekatan kualitatif.Sumber data yang digunakan adalah sumber primer dan sekunder. Pengumpulan data menggunakan observasi, wawancara, dan dokumentasi. Teknik keabsahan data menggunakan triangulasi dan cross cek. Analisis data menggunakan reduksi data, penyajian data, dan penarikan kesimpulan dan verifikasi. Hasil penelitian menunjukkan bahwa peranan balai permasyarakatan (BAPAS) dalam pembimbingan anak nakal yaitu membantu, membimbing, dan mengawasi latihan kerja anak nakal berdasarkan putusan pengadilan yang dijatuhi pidana bersyarat, pidana pengawasan, pidana denda diserahkan kepada negara dan yang memperoleh pembebasan bersyarat dari Lembaga Pemasyarakatan. Hambatan-hambatan yang dihadapi oleh BAPAS Kelas II Madiun dalam pembimbingan anak nakal yang dilakukan oleh Pembimbingan Kemasyarakatan Klien Anak berasal dari beberapa hal. Hambatan itu adalah cakupan wilayah kerja BAPAS kelas II Madiun terlalu luas yaitu sekaresidenan Madiun yaitu Ngawi, Magetan, Ponorogo, dan Pacitan, lokasi tempat tinggal klien anak di pelosok, tidak ada alat komunikasi, tidak ada transportasi, dan keadaan perekonomian orang tua klien anak sehingga pembimbingan kemasyarakatan klien anak sulit mengatur jadwal kunjungan sekaligus proses bimbingan menjadi kurang efektif.
\end{abstract}

\section{Kata Kunci: Balai Permasyarakatan dan Klien Anak Nakal}

\footnotetext{
* Mahasiswa Prodi PPKn IKIP PGRI Madiun
} 


\section{PENDAHULUAN}

Pengaruh kemajuan iptek dan budaya membuatdewasa apalagi anak-anak terjebak untuk melanggar norma terutama norma hukum. Anak-anak terjebak dalam konsumerisme dan asosial yang semakin lama dapat menjerus ke tindakan kriminal, seperti pencabulan, pembunuhan, perkelahian, penjambretan, pencurian dan sebagainya. Ditambah lagi, pada era sekarang ini banyak orang tua yang disibukkan dengan urusan duniawi (materiil) sebagai upaya mengejar kekayaan, jabatan, maupun gengsi. Dengan kondisi yang demikian, anak sebagai buah hati sering dilupakan sehingga cenderung menjadi "anak nakal".

Anak nakal adalah anak yang melakukan perbuatan terlarang dan melanggar peraturan hukum yang berlaku di masyarakat seperti pencabulan, narkotika, pencurian, kekerasan, dan lain-lain. Menurut Ibu Indriyani Susanti penyebab terjadi kenakalan anak kebanyakan karena lebih kurang perhatian dan pengawasan dari keluarga dan salah pergaulan dari anak tersebut.Selain itu, menurut Kartono (2006: 109), faktor eksternal dikenal pula sebagai pengaruh alam sekitar, faktor sosial, atau faktor sosiologis adalah semua perangsang dan pengaruh luar yang menimbulkan tingkah laku tertentu pada anak-anak remaja (tindakan kekerasan, kejahatan, perkelahian massal dan seterusnya).

Kenakalan anak memberi dorongan kuat bagi pihak-pihak yang bertanggung jawab untuk lebih memperhatikan masalah kenakalan anak, seperti orang tua, kelompok edukatif di lingkungan sekolah yang berperan sebagai pendidik, dan masyarakat sebagai kesatuan yang ikut berpengaruh terhadap perkembangan anak serta pemerintah.

Menurut Bapak Djaka Sutedjo, kenakalan anak karena anak mengalami permasalahan. Anak tersebut seharusnya diserahkan kepada balai permasyarakatan (bapas). Klien anak yang dibimbing oleh balai permasyarakatan harus berdasarkan peraturan dan putusan yang diterapkan oleh balai permasyarakatan.

Senada dengan hal di atas, menurut Ibu Anik Dwi Sujayati, anak memang pada dasarnya harus 
dibimbing. Anak-anak yang dibimbing di balai permasyarakatan pada umumnya mengalami masalahmasalah yang ada dimasyarakat sehingga peran balai permasyarakatan sangat penting.

Kasus anak nakal di Madiun menunjukkan bahwa ada seseorang klien anak yang sedang dibimbing oleh BAPAS Kelas II Madiun namun melakukan tindak pidana lagi (data dokumentasi BAPAS Kelas II Madiun tahun 2015). Dari contoh kenyataan seperti ini, dapat diketahui adanya kendala dalam pembimbingan anak nakal di Madiun.Dalam hal ini, peranan BAPAS adalah memberikan pembinaan dan bimbingan kemasyarakatan kepada anak nakal untuk meningkatkan kualitas kepribadiannya agar memiliki sikap dan perilaku yang baik.

\section{METODE PENELITIAN}

Jenis penelitian ini adalah penelitian deskriptif, dengan menggunakan pendekatan metode penelitian kualitatif. Penelitian deskriptif merupakan penelitian apabila peneliti bermaksud mengetahui keadaan suatu data
(Arikunto, 2002: 30). Dengan demikian, penelitian ini akan membahas masalah aktual dan pemecahannya dengan jalan mengumpulkan, menyusun, dan mengklasifikasikan, menganalisis, dan menginterpretasikan data secara deskriptif.

Penelitian kualitatif dalam hal ini menggunakan dua jenis sumber data yaitu sumber data primer dan sumber data sekunder.Data ini dikumpulkan dengan observasi, wawancara, dan dokumentasi. Data primer dalam penelitian ini didapat dari hasil observasi dan wawancara dengan seorang Kepala SubSeksi Bimbingan Klien Anak Balai Pemasyarakatan Kelas II Madiun, dua orang Pembimbing Kemasyarakatan Klien Anak Balai Pemasyarakatan Kelas II Madiun, dan lima orang klien anak nakal Balai Permasyarakatan Kelas II Madiun.Selain dari bahan kepustakaan, data sekunder dapat diperoleh dari dokumen yang dimiliki lembaga yang bersangkutan, misalnya seperti foto-foto maupun dokumen-dokumen yang ada dalam Balai Permasyarakatan (bapas). 
Untuk mendapatkan data yang dapat dipertanggungjawabkan, dalam penelitian diperlukan teknik keabsahan data. Pada penelitian ini digunakan teknik trianggulasi dan cross cek. Teknik triangulasiberarti penelitian menggunakan teknik pengumpulan data yang berbedabeda untuk mendapatkan data dari sumber yang sama. Sumber ini didapat dari observasi partisipatif, wawancara mendalam dan dokumentasi untuk sumber data yang sama secara serempak.

Teknik analisis data terdiri atas tiga komponen yaitu reduksi data, penyajian data, dan penarikan simpulan dan verifikasi. Reduksi data merupakan proses seleksi, merangkum, pemfokusan pada halhal yang penting, dicari tema dan polanya dan membuang hal-hal yang tidak perlu. Proses ini berlangsung terus sepanjang pelaksanaan penelitian. Laporan yang disusun berdasarkan data yang diperoleh, direduksi, dirangkum, dipilih hal-hal yang pokok, difokuskan pada hal-hal yang penting. Penyajian data merupakan suatu rakitan organisasi informasi, tersusun dalam pola hubungan sehingga akan semakin mudah dipahami. Teknik penyajian data dalam penelitian kualitatif dapat dilakukan dalam berbagai bentuk seperti tabel, grafik dan sejenisnya. Penarikan kesimpulan dan verifikasi yaitu, menarik kesimpulan awal yang dikemukakan dan masih bersifat sementara dan akan berubah apabila telah ditemukan lagi bukti-bukti yang kuat yang mendukung pada tahap pengumpulan data berikutnya.

\section{HASIL DAN PEMBAHASAN}

1. Peranan Balai Permasyarakatan (Bapas) dalam Pembimbingan Anak Nakal di Madiun Menurut Bapak Djaka Sutedjo,pada dasarnya peranan Balai Permasyarakatan (bapas) adalah melakukan bimbingan terhadap klien balai permasyarakatan itu sendiri. Untuk anak nakal diluar balai permasyarakatan bukan kewenangan dari balai permasyarakatan. Selama ada penetapan di balai permasyarakatan, menjadi tanggung jawab balai permasyarakatan untuk melakukan bimbingan, pengawasan, dan kewenangannya. 
Selama anak menjadi klien di balai permasyarakatan, anak tersebut menjadi kewenangan balai permasyarakatan.

Menurut Ibu Anik Dwi Sujayati, peran balai permasyarakatan dapat mewujudkan anak-anak sebagai penerus bangsa agar menjadi anak harapan bangsa dan menjauhi perbuatan-perbuatan yang buruk sehingga tumbuh kembang menjadi anak yang baik yang dapat berorientasi pada pendidikan yang lebih baik. Balai permasyarakatanpun mempunyai tahap-tahap pembimbingan anak nakal.

Menurut Ibu Indriyani Susanti, balai permasyarakatan berperan untuk pengawasan terutama saat masih ada orang tua. Klien anak diminta datang ke balai permasyarakatan yang nantinya petugas kermasyarakatan memberikan bimbingan. Akan tetapi, petugas kemasyarakatan juga datang kerumah klien anak untuk meninjau kondisinya ada masalah atau tidak.

Peranan balai permasyarakatan yang dilakukan oleh

Pembimbing

Kemasyarakatan (PK) juga dapat ditemukan dalam Undang-Undang Nomor 3 Tahun 1997 tentang Pengadilan Anak Bab IV Pasal 34 ayat (1), yang mengatakan bahwa Pembimbingan Kemasyarakatan membantu memperlancar tugas penyidik, penuntut umum dan hakim dalam perkara anak nakal, didalam maupun diluar sidang anak dengan membuat laporan hasil penelitian kemasyarakatan (LITMAS). Membimbing, membantu, dan mengawasi anak nakal yang dijatuhi pidana bersyarat, pidana pengawasan, pidana denda diserahkan kepada negara dan harus mengikuti latihan kerja atau yang memperoleh pembebasan bersyarat dari Lembaga Pemasyarakatan (LP).

Dari beberapa penjelasan peran balai permasyarakatan diatas, dapat disimpulkan bahwa anak yang dijatuhi pidana bersyarat oleh pengadilan, menjadi kewenangan balai permasyarakatan untuk dapat membantu, membimbing, mengawasilatihan kerja anak 
tersebut. Selama klien anak sudah

ditetapkan di balai

permasyarakatan, itu sudah

menjadi tanggung jawab balai

permasyarakatan untuk

melakukan suatu bimbingan

pengawasan agar menjadikan

klien anak menjadi lebih baik lagi

dan dapat diterima di masyarakat.

2. Hambatan yang Dihadapi oleh Balai Permasyarakatan (Bapas) dalam Pembimbingan Anak Nakal di Madiun

Hambatan yang dihadapi oleh balai permasyarakatan menurut Bapak Djaka Sutedjo adalah cakupan wilayah kerja BAPAS Kelas II Madiun yang luas meliputi sekaresidenan Madiun yaitu Ngawi, Magetan, Ponorogo, dan Pacitan. Terlalu luasnya jangkauan wilayah kerja BAPAS Kelas II Madiun menjadi salah satu hambatan bagi Pembimbing Kemasyarakatan Klien Anak karena pembimbingan untuk wilayah yang jauh dari kantor BAPAS tentunya memakan waktu yang lebih lama.

Hal itu diperjelas oleh Ibu Anik Dwi Sujayati, kondisi lokasi klien anak merupakan salah satu hambatan yang dihadapi oleh BAPAS dalam pembimbingan klien anak. Lokasi tempat tinggal yang berada di pelosok dan tidak memiliki alat komunikasi membuat kesulitan dalam mengatur jadwal kunjungan. Ketika Pembimbing Kemasyarakatan Klien Anak berkunjung ke rumah klien anak tanpa berkomunikasi dengan anak tersebut, klien anak tersebut tidak sedang berada di rumah sehingga Pembimbing Kemasyarakatan Klien Anak harus menunggu sampai anak tersebut pulang atau Pembimbing Kemasyarakatan Klien Anak berkunjung lagi keesokan harinya.

Menurut Ibu Indriyana Susanti, salah satu faktor hambatan yaitu klien anak susah disuruh datang ke kantor. Keadaan ekonomi dari orang tua klien anak juga merupakan salah satu hambatan dalam proses pembimbingan anak nakal. Misalnya pada saat klien anak harus berkunjung ke BAPAS Kelas II Madiun untuk melakukan pembimbingan tentunya klien anak tersebut memerlukan 
tranportasi, apalagibagi klien anak yang yang tidak mempunyai sepeda motor harus naik bus. Terkadang orang tua tidak mempunyai uang untuk membiayai transportasi anaknya yang harus melaksanakan pembimbingan. Dengan demikian untuk frekuensi pembimbingan yang seharusnya seminggu sekali menjadi dua minggu sekali sehingga proses pembimbingan kurang efektif.

Dapat disimpulkan bahwa hambatan-hambatan yang dihadapi oleh BAPAS Kelas II Madiun dalam pembimbingan anak nakal yang dilakukan oleh Pembimbingan Kemasyarakatan Klien Anak berasal dari beberapa hal. Hambatan itu adalah cakupan wilayah kerja BAPAS kelas II Madiun terlalu luas, lokasi tempat tinggal di pelosok, tidak ada alat komunikasi, tidak ada transportasi, dan keadaan perekonomian orang tua klien anak sehingga pembimbingan kemasyarakatan klien anaksulit mengatur jadwal kunjungan sekaligus proses bimbingan menjadi kurang efektif.

\section{SIMPULAN}

Berdasarkan penelitian yang telah dilaksanakan di Balai permasyrakatan Kelas II Madiun, disimpulkan bahwa peran balai permasyarakatan dapat mewujudkan anak-anak sebagai penerus bangsa agar menjadi anak harapan bangsa dan menjauhi perbuatan-perbuatan yang buruk sehingga tumbuh kembang menjadi anak yang baik yang dapat berorientasi pada pendidikan yang lebih baik. Peranan balai permasyarakatan (BAPAS) dalam pembimbingan anak nakal yaitu membantu, membimbing, dan mengawasi latihan kerja anaknakal berdasarkan putusan pengadilan yang dijatuhi pidana bersyarat, pidana pengawasan, pidana denda diserahkan kepada negara dan yang memperoleh pembebasan bersyarat dari Lembaga Pemasyarakatan.

Hambatan-hambatan yang dihadapi oleh BAPAS Kelas II Madiun dalam pembimbingan anak nakal yang dilakukan oleh Pembimbingan Kemasyarakatan Klien Anak berasal dari beberapa hal. Hambatan itu adalah cakupan wilayah kerja BAPAS kelas II 
Madiun terlalu luas yaitu sekaresidenan Madiun yaitu Ngawi, Magetan, Ponorogo, dan Pacitan, lokasi tempat tinggal klien anak di pelosok, tidak ada alat komunikasi, tidak ada transportasi, dan keadaan perekonomian orang tua klien anak sehingga pembimbingan kemasyarakatan klien anak sulit mengatur jadwal kunjungan sekaligus proses bimbingan menjadi kurang efektif.

\section{DAFTAR PUSTAKA}

Suharsimi Arikunto. 1993. Penelitian Suatu Pendekatan Praktek. Jakarta: Rineka Cipta.

2002. Cetakan

Keduabelas.Penelitian Suatu Pendekatan Praktek. Jakarta: Rineka Cipta

Barowi dan Suwandi. 2008. Memahami Penelitian Kualitatif. Jakarta: PT Rineka Cipta.

Kartini Kartono. 2006. Kenakalan Remaja. Jakarta: PT RajaGrafindo Persada.

Hadari Nawawi. 1998. Metode Penelitian Bidang Sosial. Yogyakarta: Gajah Mada University Press.

Lexy J. Moleong. 2014. Cetakan ketiga puluh dua. Metedologi Penelitian Kualitatif. Bandung: PT Remaja Rosdakarya.

Joko Subagyo. 2004. Metode Penelitian. Jakarta : PT Asdi Mahasatya.

Sugiono. 2013. Metode Peneliti Kuantitatif, Kualitatif, Dan, $R \& D$. Bandung: Penerbit Alfabeta.

Undang-Undang.2003. Perlindungan Anak Nomor 23 Tahun 2012. Jakarta: Sinar Grafika.

Widodo. 2012. Prisonisasi Anak Nakal. Yogjakarta: Aswaja Pressindo. 